\title{
Outbreak of ciguatera food poisoning by consumption of amberjack (Seriola spp.) in the Canary Islands, May 2012
}

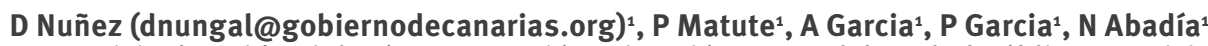

1. Servicio de Epidemiología y Prevención, Dirección General de Salud Pública, Servicio Canario de la Salud, Canary Islands, Spain

In May 2012 a family outbreak of ciguatera food poisoning, affecting four people, was detected in Tenerife, Canary Islands. The outbreak was caused by eating amberjack fish (Seriola spp.) bought in a local market. This is the third outbreak of ciguatera food poisoning in the Canary Islands in 2012. We describe the epidemiology of this outbreak.

\section{Outbreak description}

In mid-May 2012, a primary healthcare centre in Tenerife reported a case compatible with ciguatera food poisoning, according to the criteria established by the Epidemiological Surveillance System for Ciguatera poisoning in the Canary Islands (SVEICC) [1]. The next day, another primary healthcare centre located in a different town notified a second compatible case. The second case belonged to the same family as the index case. An investigation was initiated, and two more cases were subsequently found, also with symptoms consistent with ciguatera poisoning. The four cases consisted of a man and three women, aged in their mid-30s to early 6os. The symptoms presented by the cases are detailed in Table 1 . Although three cases were treated, none required hospitalisation.

\section{Food investigation}

Questioning cases about their food history revealed that all had shared a common meal. The onset of symptoms had occurred between five and 36 hours after ingestion of a food item served during this meal.

The food eaten by all cases was made with fish of the species amberjack (Seriola spp.), which had been bought two months earlier in a local market, and frozen until the date of consumption. It was a $2 \mathrm{~kg}$ piece of fish, the origin of which is currently being sought. The only remains of the consumed meal was a soup made with the fish in question, which is being analysed to confirm the presence of ciguatoxin, the toxin responsible for ciguatera poisoning.

\section{TABLE 1}

Symptoms of cases with ciguatera food poisoning, Canary Islands, Spain, May 2012 (n=4)

\begin{tabular}{|c|c|c|c|c|}
\hline \multirow{2}{*}{ Symptom } & \multicolumn{4}{|c|}{ Presence $(+)$ or absence $(-)$ of symptom in cases } \\
\hline & Case 1 & Case 2 & Case 3 & Case 4 \\
\hline Vomiting & + & - & - & - \\
\hline Diarrhoea & + & + & + & + \\
\hline Nausea & + & + & + & - \\
\hline Abdominal pain & + & + & - & - \\
\hline Tingling lips, hands and legs & + & + & - & + \\
\hline Paradoxical thermal sensation & + & - & - & + \\
\hline Pruritus & + & + & + & + \\
\hline Fatigue & + & + & + & - \\
\hline Myalgia & + & + & + & + \\
\hline Swelling eyelids and hands & + & - & - & - \\
\hline Cramps & - & + & - & - \\
\hline Dizziness & - & - & - & + \\
\hline
\end{tabular}




\section{Background}

Ciguatera is a type of food poisoning caused by eating fish contaminated with ciguatoxin. Typically the implicated fish are large predator species that have accumulated toxin provided by herbivore fish that feed on algae and toxic dinoflagellates found on coral reefs (e.g. Gambierdiscus toxicus). The toxin is concentrated through the food chain, ultimately reaching the human consumer. Larger and older fish are often more toxic [2]. People who have ciguatera may experience nausea, vomiting, and neurologic symptoms such as tingling fingers or toes; they also may find that cold things feel hot and hot things feel cold. Onset usually occurs within 10 minutes to 24 hours after ingestion of toxic fish. Symptoms usually go away in days or weeks but can last for years. People who have ciguatera can be treated for their symptoms. Ciguatera has no cure [3].

\section{Situation in Europe}

In Europe, there have been reports of ciguatera poisoning related to travel to endemic countries boarding the Caribbean Sea or the Red Sea [2]. No indigenous cases have been reported in Spain but an outbreak occurred in 2004 associated with consumption of amberjack fish (Seriola spp.) captured in Canarian waters [4]. In 2008, an outbreak of ciguatera in Madeira, Portugal, was reported, due to consumption of amberjack fish caught in local waters [5]. Furthermore, some studies have identified the presence of Gambierdiscus spp. in waters surrounding the Canary Islands and Madeira [6], but there are still many gaps in knowledge regarding their prevalence, how long they have been present, the type(s) of toxin they produce, and the accumulation of toxins in the surrounding marine life [7].

An autochthonous outbreak of ciguatera food poisoning occurred in the Canary Islands in 2008 and was associated with consumption of fish purchased in the local market $[8,9]$.
Surveillance initiatives in the Canary Islands Following this second outbreak which affected 25 people, the SVEICC was launched in 2009. The SVEICC is based on urgent and compulsory notification of all cases that are treated in the healthcare system with symptoms consistent with ciguatera (suspected cases), and the collection of basic data on a case-specific epidemiological questionnaire. The 'suspected case' definition includes a history of consuming fish from any of the varieties considered at risk (amberjack, abbot, grouper, silverside, barracuda, moray eel, wahoo and Atlantic bonito) and the presence of clinical symptoms. Both the SVEICC and the specific epidemiological questionnaire are available on the Canary Islands Health Service website [1].

The food research done for each case of suspected ciguatera poisoning includes information on the date and place of capture of fish, their origin, weight and size, and place of distribution or sale. It also gives priority to location and collection of a sample of the product consumed (for laboratory confirmation) and the destruction of the remains of involved fish to avoid its consumption.

\section{Epidemiological surveillance results}

In addition to the most recent outbreak reported here, the SVEICC recorded eight indigenous outbreaks of ciguatera food poisoning between November 2008 and April 2012, according to data from the Epidemiology and Prevention Service of de General Directorate of Public Health. The total number of people who have been affected up to now is 68. The following table contains information broken down for each of the outbreaks: date of onset, number of cases, species of fish associated with the outbreak, weight and their origin.

In three of the outbreaks, presence of ciguatoxin in the food eaten was confirmed.

\section{TABLE 2}

Outbreaks ( $n=9)$ and number of cases $(n=68)$ of ciguatera food poisoning, Canary Islands, Spain 2008-2012

\begin{tabular}{|c|c|c|c|c|c|c|}
\hline $\begin{array}{l}\text { Outbreak } \\
\text { number }\end{array}$ & Date & Island & $\begin{array}{c}\text { Number of } \\
\text { human cases }\end{array}$ & Fish species & Weigth (kg) & Origin \\
\hline 1 & $15 / 11 / 2008$ & Tenerife & 25 & Amberjack (Seriola fasciata) & 37 & Local market \\
\hline 2 & 29/01/2009 & Tenerife & 4 & Amberjack (Seriola dumerilis) & 67 & Sport fishing \\
\hline 3 & $03 / 09 / 2009$ & Gran Canaria & 3 & Amberjack (Seriola spp.) & Unknown & Unknown \\
\hline 4 & $19 / 11 / 2009$ & Tenerife & 2 & Amberjack (Seriola spp.) & Unknown & Sport fishing \\
\hline 5 & $24 / 04 / 2010$ & Tenerife & 6 & Amberjack (Seriola spp.) & 80 & Unknown \\
\hline 6 & $26 / 06 / 2011$ & Gran Canaria & 5 & Amberjack (Seriola spp.) & 24 & Sport fishing \\
\hline 7 & $28 / 01 / 2012$ & Lanzarote & 10 & Amberjack (Seriola spp.) & 15 & Sport fishing \\
\hline 8 & $04 / 04 / 2012$ & Lanzarote & 9 & Amberjack (Seriola spp.) & 26 & Sport fishing \\
\hline 9 & $05 / 2012$ & Tenerife & 4 & Amberjack (Seriola spp.) & Unknown & Local market \\
\hline
\end{tabular}




\section{Conclusions}

Epidemiological surveillance activities indicate that ciguatera food poisoning occurs in the Canary Islands. All documented outbreaks since 2004 have been associated with the consumption of large amberjack. To date, no other species has been identified in relation to outbreaks. Most of the outbreaks are linked to sport fishing activities.

Ciguatera poisoning is an emergent process in the Canary Islands, with a persistent incidence of outbreaks and an impact on public health. However, the number of cases remains lower than an average of 12 cases per year, so the risk of contracting the disease in the Canary Islands is very low. Moreover there are still many unknowns regarding the origin of the problem and the real meaning of the presence of Gambierdiscus spp. (producers of ciguatoxin) [5-7] in our marine environment.

\section{References}

1. Servicio de Epidemiología y Prevención. Dirección General de Salud Pública. Gobierno de Canarias. Protocolo de actuación para la vigilancia epidemiológica de la intoxicación por ciguatera en Canarias [Protocol for the epidemiological surveillance of ciguatera poisoning in the Canary Islands]. [Accessed 6 Jun 2012]. Spanish. Available from: http://www2.gobiernodecanarias.org/sanidad/scs/ contenidoGenerico.jsp?idDocument=bb179ged-b4co-11deae50-15aa3b923ob7\&idCarpeta $=1$ f358add-07f8-11de-8a2df3b13531fc76

2. Food and Agriculture Organization of the United Nations (FAO). FAO Food and Nutrition Papers v 80. Marine biotoxins. Rome: FAO. 2004. Available from: http://www.fao.org/docrep/o07/ y5486e/y5486eoq.htm\#bm26

3. Centers for Disease Control and Prevention (CDC). National Center for Environmental Health. Ciguatera fish poisoning. Atlanta: CDC. [Accessed 6 Jun 2012]. Available from: http:// www.cdc.gov/nceh/ciguatera/default.htm\#about

4. Pérez-Arellano JL, Luzardo OP, Pérez Brito A, Hernández Cabrera M, Zumbado M, et al. Ciguatera Fish Poisoning, Canary Islands. Emerg Infect Dis. 2005;11(12):1981-2.

5. European Food Safety Authority (EFSA). EFSA Panel on Contaminants in the Food Chain. Scientific Opinion on marine biotoxins in shellfish - Emerging toxins: Ciguatoxin group. EFSA Journal; 2010 8(6):1627. Available from : http://www.efsa. europa.eu/en/efsajournal/doc/1627.pdf

6. Fraga S, Rodríguez F, Caillaud A, Diogène J, Raho N, Marín I, et al. Ciguatera y Gambierdiscus en la Macaronesia [Ciguater and Gambierdiscus in Macaronesia]. XI Reunión Ibérica sobre Microalgas Nocivas y Biotoxinas; 201130 May-2 June; Bilbao, Spain. Spanish. [Accessed 6 Jun 2012]. Available from: http:// www.ehu.es/reunioniberica/images/stories/Resmenes_final. doc

7. Caillaud A, Cañete E, Fraga S, Mallat y E, Diogène J. Toxicidad de la dinoflagelada Gambierdiscus sp. aislada de las Islas Canarias [Toxicity of the dinoflagellate Gambierdiscus spp. isolated from the Canary Islands]. IX Reunión Ibérica de grupo de Trabajo multidisciplinar sobre fitoplancton tóxico y biotoxinas; 2007 May 7-10; Cartagena, Spain. Spanish.

8. Matute P, Núñez D, Abadía N. Caracterización de dos brotes autóctonos de intoxicación alimentaria por ciguatera ocurridos en Tenerife en noviembre de 2008 y enero de 2009 [Characterisation of two indigenous outbreaks of ciguatera food poisoning which occurred in Tenerife in November 2008 and January 2009]. XXXVII Reunión de la Sociedad Española de Epidemiología; 2009 Oct 28-30; Zaragoza, Spain. Spanish.

9. Boada LD, Zumbado M, Luzardo OP, Almeida-González M, Plakas SM, Granade HR, et al. Ciguatera fish poisoning on the West Africa Coast: An emerging risk in the Canary Islands (Spain). Toxicon. 2010;56(8):1516-9. 